\title{
Implementasi Adaptasi Baru melalui KKN UNS di Era Covid 19
}

\author{
Djono \\ Fakultas Ilmu Pendidikan dan Keguruan, Universitas Sebelas Maret \\ Email : djono@staff.uns.ac.id
}

\begin{abstract}
The Student Study Service (KKN) is a form of community to service that is carried out in the face of the COVID-19 outbreak. KKN is carried out individually, located in the area where the student lives. Based on the results of research in the field, it was found that there was a lack of understanding of the COVID-19 virus and the prevention of COVID-19. Also, the community, especially students who are in the Distance Learning process (PJJ), are less facilitated in the academic field. The KKN program is implemented in two ways, namely offline and online. Programs carried out offline are socialization about COVID-19 to the surrounding community, distribution of masks to the community, the practice of washing hands together with children, tutoring programs for children, and socialization of new norms and protocols that must be implemented. while the programs implemented online are online group guidance, making educational videos, and disseminating them to social media accounts. The implementation of this real lecture has good implications for the surrounding community, the community becomes more vigilant and complies with health protocols, and learning that students do during the PJJ period can be more enjoyable.
\end{abstract}

Keywords: The Student Study Service (KKN), COVID-19, COVID-19 Prevention.

\begin{abstract}
ABSTRAK
Kuliah Kerja Nyata (KKN) merupakan bentuk pengabdian kepada masyarakat yang dilaksanakan dalam menghadapi wabah COVID-19. KKN dilaksanakan secara individu yang berlokasi di daerah tempat tinggal mahasiswa. Berdasarkan hasil penelitian di lapangan, ditemukan kurangnya pemahaman mengenai virus COVID-19 beserta pencegahan COVID-19. Selain itu, masyarakat terutama peserta didik yang sedang dalam proses Pembelajaran Jarak Jauh (PJJ) kurang terfasilitasi dalam bidang akademik. Program KKN dilaksanakan melalui dua cara, yaitu luring dan daring. Program yang dilakukan secara luring adalah sosialisasi mengenai COVID-19 kepada masyarakat sekitar, penyaluran masker kepada masyarakat, praktik mencuci tangan bersama dengan anak-anak, program bimbingan belajar kepada anak-anak serta sosialisasi mengenai new normal dan


protokol yang harus dijalankan. sedangkan program yang dilaksanakan secara daring adalah bimbingan kelompok online, membuat video edukasi dan menyebarluaskannya ke akun sosial media. Pelaksanaan kuliah kerja nyata ini memberikan implikasi yang baik bagi masyarakat sekitar, masyarakat menjadi lebih waspada dan lebih menaati protokol kesehatan, serta pembelajaran yang dilakukan peserta didik dalam masa PJJ dapat lebih menyenangkan.

Kata kunci: Kuliah Kerja Nyata (KKN), COVID-19, Pencegahan COVID-19.

DOI: https://dx.doi.org/10.20961/dedikasi.v2i2.45927

\section{PENDAHULUAN}

Coronavirus adalah sekelompok virus yang dapat menyebabkan penyakit pada hewan atau manusia. Beberapa jenis virus corona diketahui menyebabkan infeksi saluran pernapasan pada manusia, mulai dari pilek hingga batuk yang lebih parah seperti Middle East Respiratory Syndrome (MERS) dan Severe Acute Respiratory Syndrome (SARS) (Guan dkk., 2020). Coronavirus yang baru ditemukan dapat menyebabkan penyakit COVID-19 (WHO, 2020). Sejauh ini, ketika orang yang terinfeksi batuk atau bersin, melalui tetesan air liur atau keluar dari hidung, penyakit coronavirus-2019 (COVID-19) menyebar semakin cepat. Gejala dan tanda umum infeksi COVID-19 antara lain gejala penyakit pernapasan akut, seperti demam, batuk, dan sesak napas. Masa inkubasi rata-rata adalah 5 sampai 6 hari, dan masa inkubasi terlama adalah 14 hari. (Yurianto. 2020)

Karena penyebaran virus yang cukup masif maka pemerintah pusat maupun daerah membuat kebijakan untuk menekan angka penyebaran virus Covid-19 (Widiyani, 2020) . Beberapa hal penting yang perlu dilakukan adalah bagaimana mengurangi mobilitas orang dari satu tempat ke tempat yang lain, menjaga jarak, dan mengurangi kerumunan orang yang membawa risiko lebih besar pada penyebaran Covid-19, dan melakukan tindakan preventif seperti mencuci tangan dan memakai masker. Kebijakan belajar dari rumah, bekerja dari rumah, dan beribadah di rumah perlu terus digencarkan, untuk mengurangi tingkat penyebaran Covid-19 dengan tetap mempertahankan pelayanan kepada masyarakat, urusan kebutuhan pokok, pelayanan kesehatan, dan layanan publik lainnya (Perdana, 2020; Kottasova, 2020).

Penyebaran virus korona yang awalnya berdampak besar pada perekonomian dunia, dan ekonomi dunia mulai melambat, namun kini sektor pendidikan juga merasakan dampak tersebut. Banyak negara (termasuk Indonesia) telah mengadopsi kebijakan untuk menutup semua kegiatan pendidikan, yang 
mengharuskan pemerintah dan lembaga terkait untuk memberikan prosedur pendidikan alternatif kepada siswa (Kemendikbud, 2020) .

Dari Kondisi tersebut, mahasiswa Universitas Sebelas Maret melakukan Kuliah Kerja Nyata dalam bentuk menjadi relawan Covid 19 dengan tujuan untuk dapat membantu masyarakat khususnya di tempat tinggal masing-masing dalam hal meningkatkan kesadaran dalam bahaya Covid 19, upaya penanggulangan persebaran Covid 19, serta membantu anak-anak sekolah dalam mengikuti pembelajaran selama di rumah di tengah pandemi Covid 19.

\section{METODE}

Metode kegiatan KKN yang dilakukan oleh tim KKN menggunakan metode observasi dan mengunjungi langsung lokasi KKN. KKN dilaksanakan di kawasan tempat tinggal mahasiswa mulai tanggal 15 Mei hingga 30 Juni 2020. Metode implementasi yang diadopsi oleh KKN Covid-19 adalah dengan melakukan pengajaran secara offline dan online, interaksi sosial online dan offline, serta edukasi tentang pencegahan penyebaran virus Covid-19 dan informasi terkini. Terkait Covid-19, starter kit yang dibagikan berupa masker wajah, hand sanitizer dan adaptasi kebiasaan baru, serta kegiatan yang bisa dilakukan selama pandemi Covid-19.Media dan fasilitas yang digunakan antara lain adalah pembagian starter kit dan poster melalui media sosial seperti WhatsApp, YouTube dan Instagram. Poster yang dihasilkan digunakan untuk memberikan pemahaman dan gambaran kepada masyarakat untuk menjaga kesehatan dan menghindari tempat berkumpul untuk mencegah penyebaran COVID-19.

\section{HASIL DAN PEMBAHASAN}

Dari Program KKN dilakukan dengan menerapkan protokol pemerintah yaitu work from home dan social distancing (Wilder-Smith \& Freedman, 2020). Adapun program yang akan dilakukan yaitu Supporting Keselamatan Masyarakat terhadap COVID-19. KKN dilakukan pada bulan Mei 2020 melalui beberapa kegiatan yang selanjutnya dapat diajarkan dan edukasi protokol kesehatan di lingkungan sekitar, Detail kegiatan Program KKN UNS Era COVID-19 yang dilakukan dapat dilihat pada Gambar 1. 


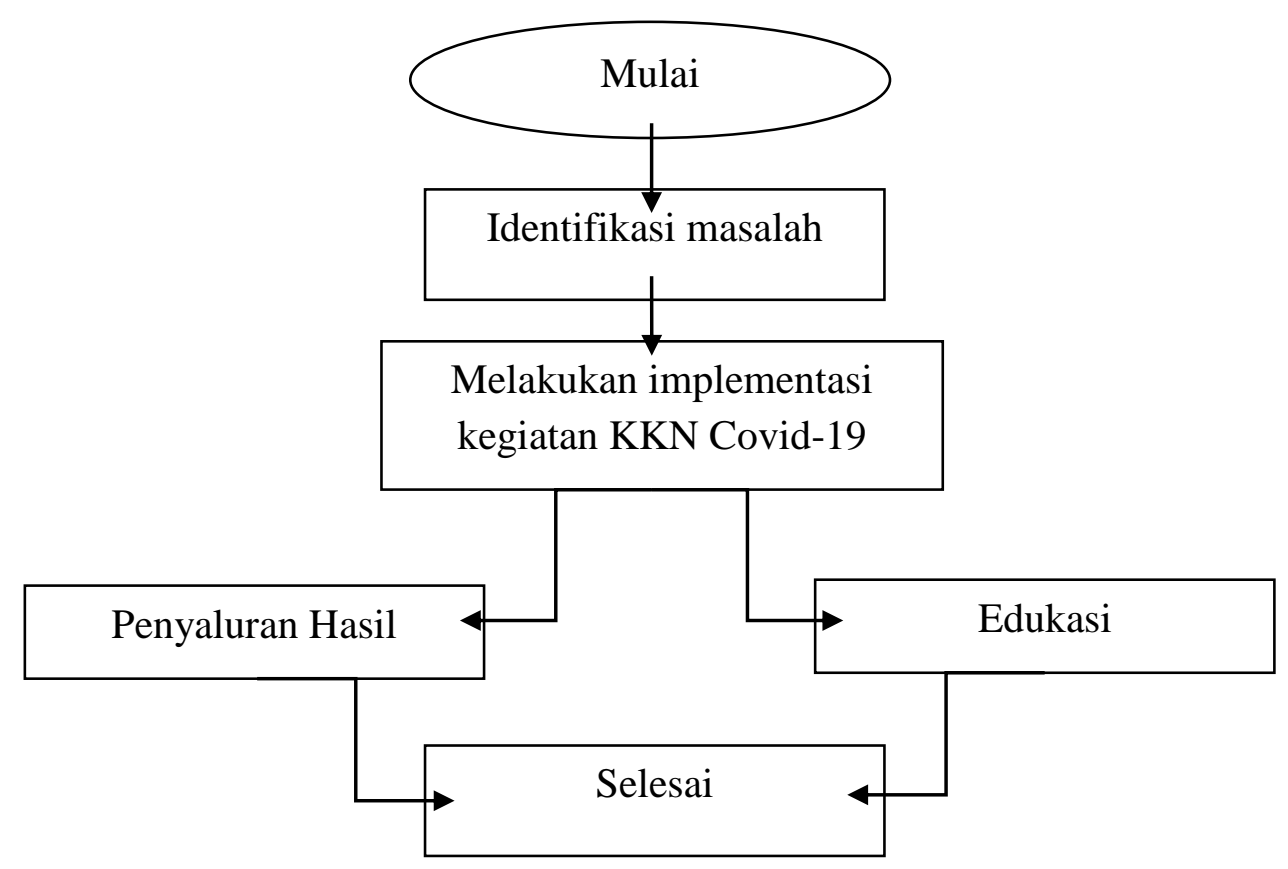

Gambar 1. Alur KKN

\section{Identifikasi Masalah}

Dari latar belakang masalah yang ada, program KKN yang dilakukan berdasarkan kalsifikasi yang terdapat pada Tabel 1 .

Tabel 1. Tabel alternatif permasalahan

\begin{tabular}{|c|c|c|c|}
\hline NO & Masalah & $\begin{array}{c}\text { Alternatif } \\
\text { Permasalahan }\end{array}$ & Bentuk Kegiatan \\
\hline 1 & $\begin{array}{l}\text { Pemahaman tentang } \\
\text { Covid-19 di masyarakat } \\
\text { yang masih rendah }\end{array}$ & $\begin{array}{l}\text { Memberikan Edukasi } \\
\text { tentang Covid-19 serta } \\
\text { kiat-kiat pencegahannya }\end{array}$ & $\begin{array}{l}\text { Melakukan } \\
\text { pembuatan poster } \\
\text { edukasi, banner } \\
\text { edukasi, dan stiker } \\
\text { edukasi yang } \\
\text { kemudian } \\
\text { dibagikan pada } \\
\text { tiap warga }\end{array}$ \\
\hline 2 & $\begin{array}{l}\text { Pembelajaran daring dari } \\
\text { sekolah yang kurang } \\
\text { optimal }\end{array}$ & $\begin{array}{l}\text { Melakukan pembuatan } \\
\text { modul pembelajaran }\end{array}$ & $\begin{array}{l}\text { Melakukan } \\
\text { tambahan kelas } \\
\text { daring dan luring } \\
\text { dengan mengikuti } \\
\text { protocol } \\
\text { kesehatan. }\end{array}$ \\
\hline
\end{tabular}




\section{Implementasi KKN era Covid-19}

a. Pendampingan belajar mandiri dan bimbingan belajar

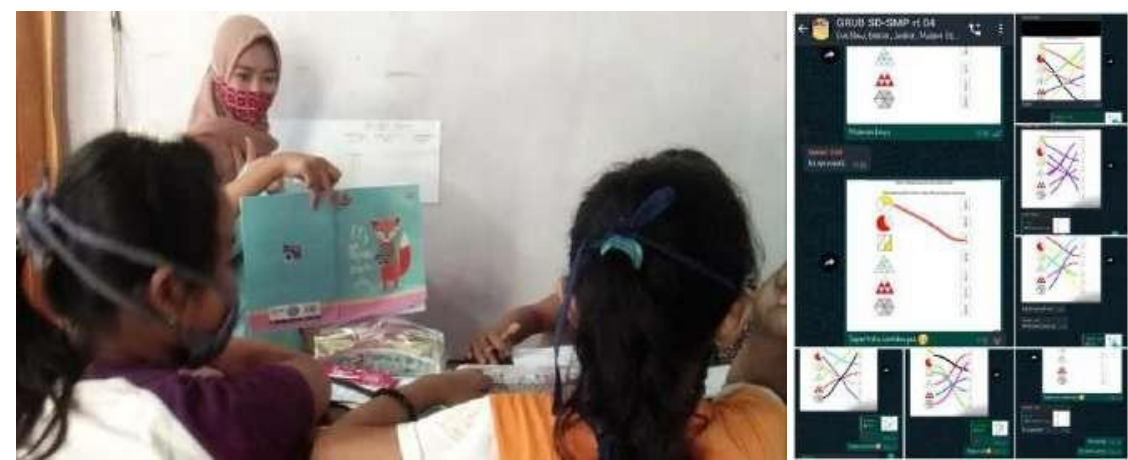

Gambar 2. Mahasiswa UNS melakukan pendampingan belajar

Program pendampingan belajar dilaksanakan secara online dan offline mulai 11 Mei hingga 15 Juni, program secara online dilaksanakan melalui Whatsapp dan program secara offline dilaksanakan rutin seminggu 3 kali seminggu dengan jadwal hari rabu, kamis, dan sabtu. Program offline dilaksanakan dengan tetap mematuhi protokol kesehatan dengan menjaga jarak, menggunakan handsanitizer, dan memakai masker. Program ini bertujuan untuk membantu siswa SD-SMP yang mengalami kesulitan belajar dan membutuhkan pendampingan belajar mengerjakan tugas sekolah. Selain itu, program ini juga memberikan edukasi terkait Covid-19 secara dini melalui modul bergambar, video animasi yang menarik dan menggambar serta mewarnai.

Hasil yang dicapai dari terlaksananya program ini adalah siswa mendapatkan ilmu yang bermanfaat mengenai materi sekolah dan pemahaman terkait Covid-19 dan siswa dapat membiasakan menerapkan protokol kesehatan sehingga dapat mempersiapkan diri menghadapi new normal pada saat nantinya mereka akan kembali bersekolah. Selain itu, mereka merasa senang karena dapat belajar bersama teman. Program ini sangat efektif untuk membiasakan anak menerapkan protokol kesehatan, edukasi dini tentang Covid-19 dan mengisi kegiatan positif pada jam belajar. 
Setelah KKN selesai program ini tetap berjalan atas permintaan siswa dan orang tua siswa, dikarenakan mulai tahun ajaran baru siswa masih tetap belajar dari rumah.Pendampingan belajar tetap dapat dilaksanakan secara online melalui Whatsapp Group maupun offline dengan menyesuaikan waktu relawan. Siswa SD sangat antusias dan berpartisipasi mengenai kegiatan ini tetapi untuk siswa SMP lebih berpartisipasi pada kegiatan belajar secara online melalui Whatsapp Group.

b. Sosialisasi pendidikan masa pandemi kepada guru dan orang tua

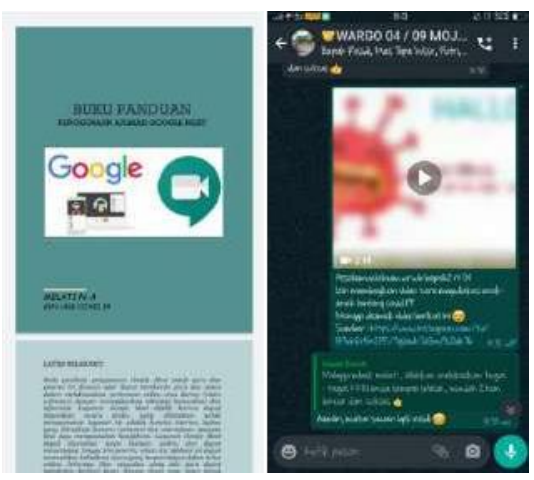

Gambar 3. Screenshoot file modul dan sosialisasi orang tua

Sosialisasi media pembelajaran dilakukan dengan penyusunan modul panduan aplikasi google meet kepada guru dan juga siswa. Kemudian, dilakukan uji coba dengan guru. Sosialisasi kepada orang tua melalui grub untuk mendampingi dan mengawasi anak mereka ketika belajar dari rumah mulai dari memberikan pemahaman sejak dini tentang Covid-19 melalui video animasi hingga mengisi kegiatan yang bermanfaat seperti belajar sambil bermain.

Hasil yang dicapai dari terlaksananya program ini adalah modul yang disusun dapat bermanfaat bagi guru dan siswa sebagai panduan pembelajaran online yang dapat dilaksanakan pada tahun ajaran baru. Hasil sosialisasi kepada orang tua memberikan bahan 
untuk dapat lebih dekat dengan anak dan meluangkan waktu lebih untuk mendampingi anak belajar di masa pandemi.

Modul panduan penggunaan google meet dapat di manfaatkan untuk kegiatan belajar mengajar pada tahun ajaan baru agar siswa juga tidak bosan jika pembelajaran hanya melalui whatsapp group.

\section{c. Pembuatan dan Pembagian Masker Kain}

Program pembuatan masker kain diselenggarakan untuk membantu perekonomian penjahit masker di Kampung Bratan yang terkendala karena adanya Covid-19. Pembagian masker kain di wilayah Kampung Bratan untuk meningkatkan kesadaran masyarakat agar selalu menggunakan masker ketika beraktivitas di luar rumah. Jumlah positif Covid-19 di Surakarta yang meningkat belum diikuti dengan kesadaran masyarakat untuk menjaga pola hidup bersih dan sehat. Padahal, kesadaran masyarakat merupakan salah satu faktor utama pemutus mata rantai penyebaran Covid-19. Kondisi tersebut merupakan latar belakang KKN UNS untuk mengadakan program pembuatan dan pembagian masker. Melalui brosur yang dimasukkan dalam kemasan masker, masyarakat akan mengetahui bagaimana cara menggunakan dan merawat masker kain yang baik. Selain itu, brosur yang menarik dapat membangkitkan kesadaran masyarakat untuk menggunakan masker.

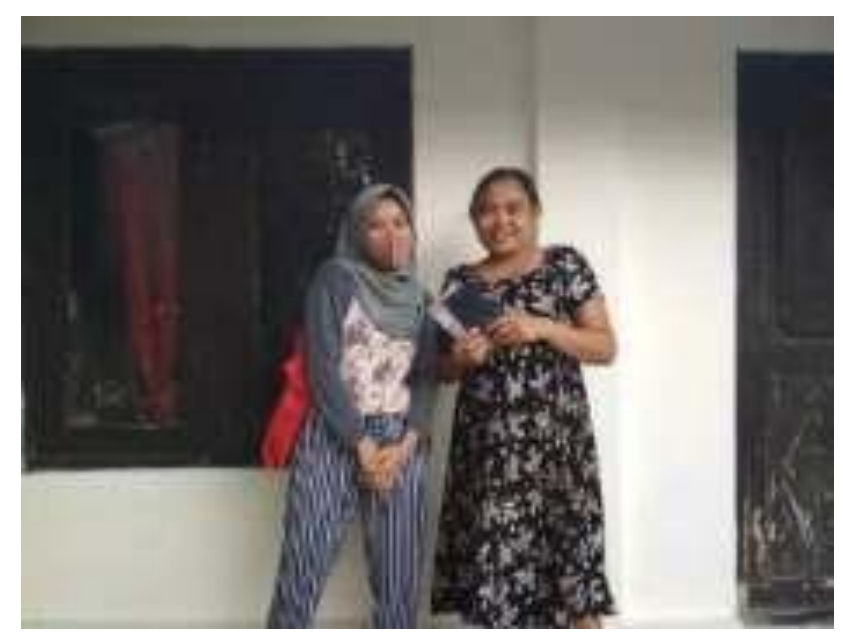


Gambar 4. Mahasiswa UNS membagikan Masker

\section{d. Pengadaan Tempat Cuci Tangan Beserta dengan Edukasi Cara Mencuci Tangan yang Benar}

Kegiatan pengadaan tempat cuci tangan dilakukan pada tanggal 29-30 Mei 2020 dan ditempatkan di pos ronda sebagai tempat umum yang seringkali didatangi oleh warga Kampung Bratan. Fasilitas ini dilengkapi dengan ember kran, kursi plastik, dan sabun cair. Pengadaan tempat cuci tangan juga dilengkapi dengan memberikan sosialisasi cara mencuci tangan yang baik dan benar kepada warga. Setelah dilakukan pemasangan tempat cuci tangan dan sosialisasi cara mencuci tangan, dilanjutkan dengan pelaporan dan diskusi
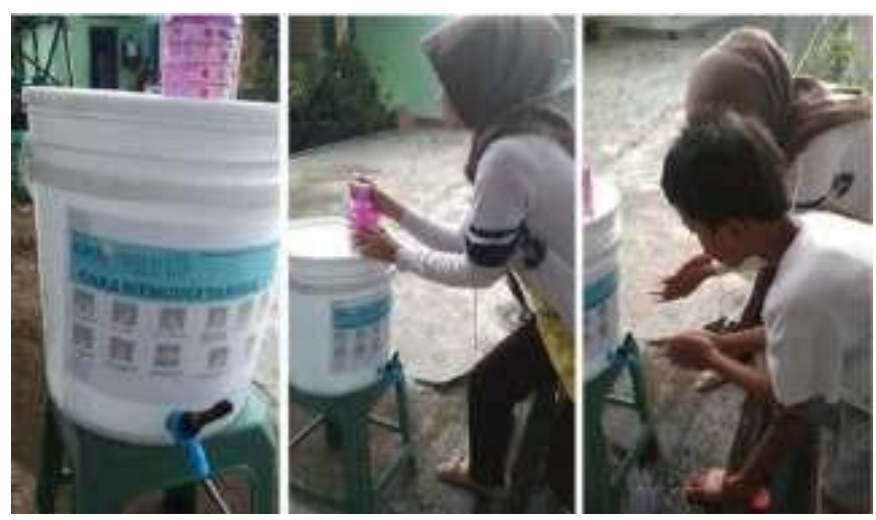

Gambar 5. Pengadaan tempat cuci tangan dan edukasi cara mencuci tangan

\section{Edukasi}

a. Pembagian Leaflet tentang Kehidupan New Normal 


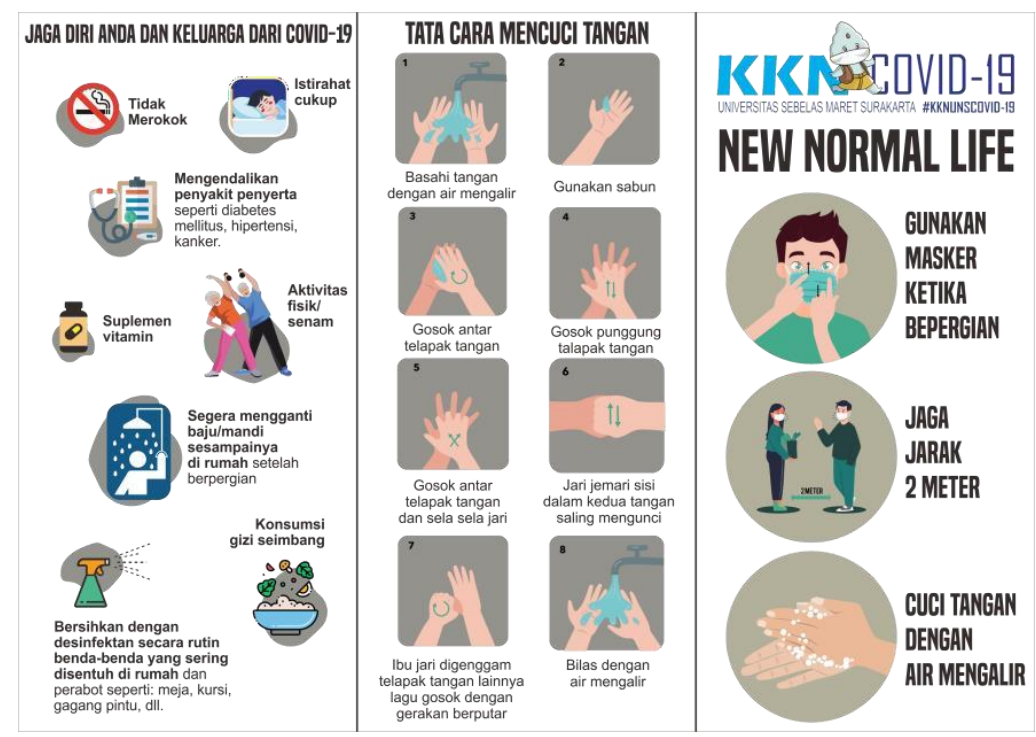

Gambar 6. Leaflet kehidupan New Normal

Pembagian Leaflet tentang kehidupan new normal untuk masyarakat RT 04/RW 09, Kelurahan Tebet Timur. Leaflet ini berisi tentang himbauan untuk memakai masker, menjaga jarak dan selalu cuci tangan dengan air mengalir. Leaflet tersebut juga memberikan tata cara mencuci tangan dan cara pencegahan penularan Virus Covid-19. Leaflet dibagikan di pagar-pagar rumah untuk mencegah penuluran Virus Covid19. Leaflet juga dibagikan di akses masuk jalan untuk pengunjung yang memasuki perumahan tersebut.

\section{b. Publikasi Poster Online di Media Sosial}

Program kerja selanjutnya adalah publikasi poster yang terkait dengan Virus Covid-19. Poster tersebut disebarkan di media sosial yang berfungsi untuk mengedukasi masyarakat tentang hal-hal yang berkaitan dengan pencegahan penyebaran Virus Covid-19. 


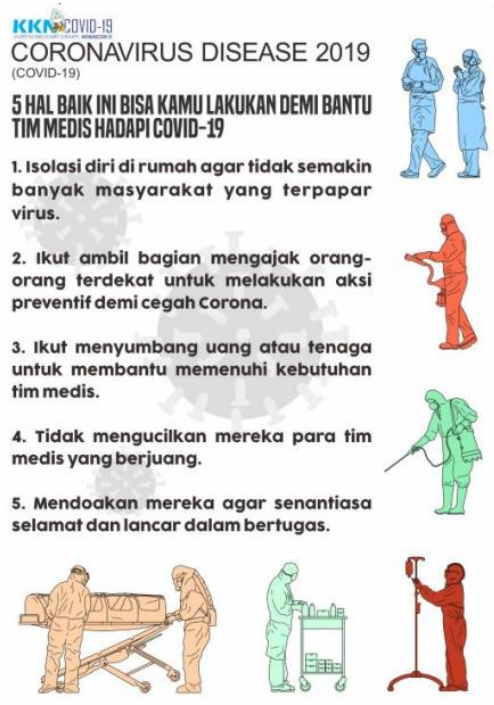

Gambar 7. Poster Online berisi informasi tentang covid-19

\section{c. Pembuatan Konten dan Video Edukasi Mengenai COVID-19}

Pembuatan konten dan video edukasi mengenai COVID-19 dilaksanakan sebanyak 4 kali. Pada konten edukasi pertama disebarkan melalui instagram pribadi mahasiswa $\mathrm{KKN}$ mengenai pengertian COVID-19 dan gejalanya apabila terdampak COVID-19. Lalu video edukasi yang dibuat cara membuat disinfektan sendiri yang di unggah ke youtube mahasiswa KKN dengan tujuan masyarakat dapat menonton dan dapat membuat disinfektan sendiri guna mencegah penyebaran COVID19. Disinfektan sendiri dapat dipakai setelah bepergian dari luar dengan cara menyemprotkan ke barang-barang yang dibawa saat bepergian. Video edukasi yang kedua adalah mengenai panduan mencegah penyebaran COVID-19. Video edukasi yang ketiga adalah panduan mencuci tangan yang benar yang dilakukan oleh anak-anak (akan dibahas dipoin berikutnya). Dan video edukasi yang terakhir adalah mengenai tips sehat dalam menghadapi new normal. Tujuan dari pembuatan video edukasi ini adalah untuk memberikan pemahaman kepada masyarakat mengenai COVID-19, dan New Normal agar masyarakat dapat lebih memberikan atensi kepada kedua hal tersebut dan dapat menerapkan 
protokol kesehatan yang benar terutama dalam menghadapi new normal.

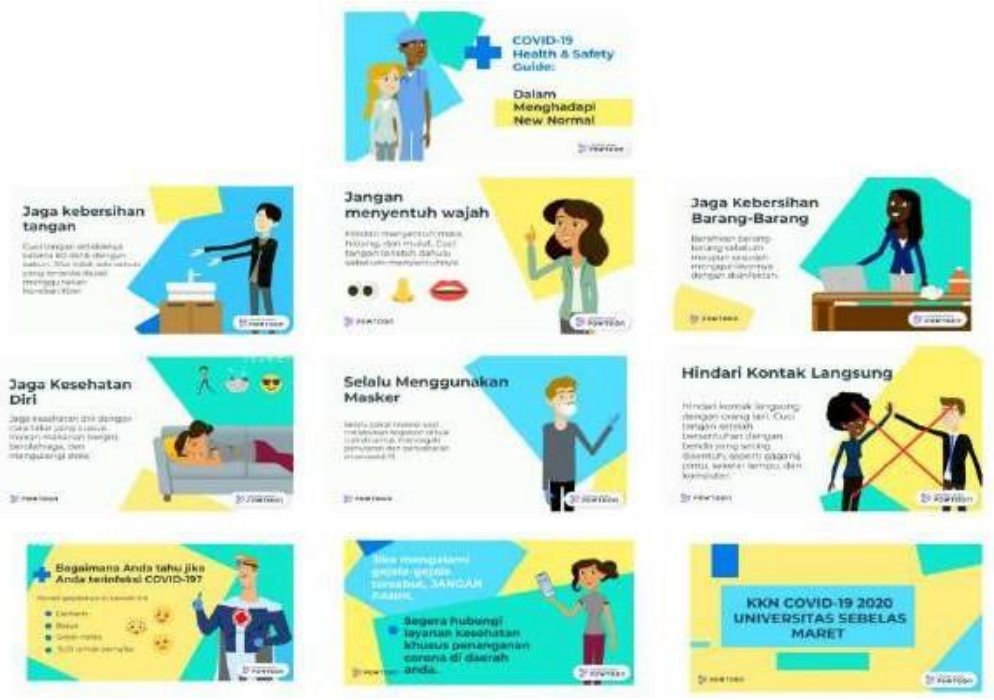

Gambar 8. Tips sehat dalam menghadapi new normal

\section{d. Edukasi PHBS}

Mencuci tangan merupakan hal yang sangat penting untuk diterapkan terlebih dimasa COVID-19. Praktik mencuci tangan ini dilakukan dengan tujuan mengedukasi anak-anak mengenai pentingnya mencuci tangan dan memberikan pengetahuan bagaimana cara mencuci tangan yang benar. Anak-anak dibimbing dan diberikan instruksi untuk mencuci tangannya. Setelah selesai mempraktikkan cuci tangan, anakanak menjadi lebih paham dan mengerti bagaimana panduan mencuci tangan yang benar dan mampu mempraktikkannya di rumah.

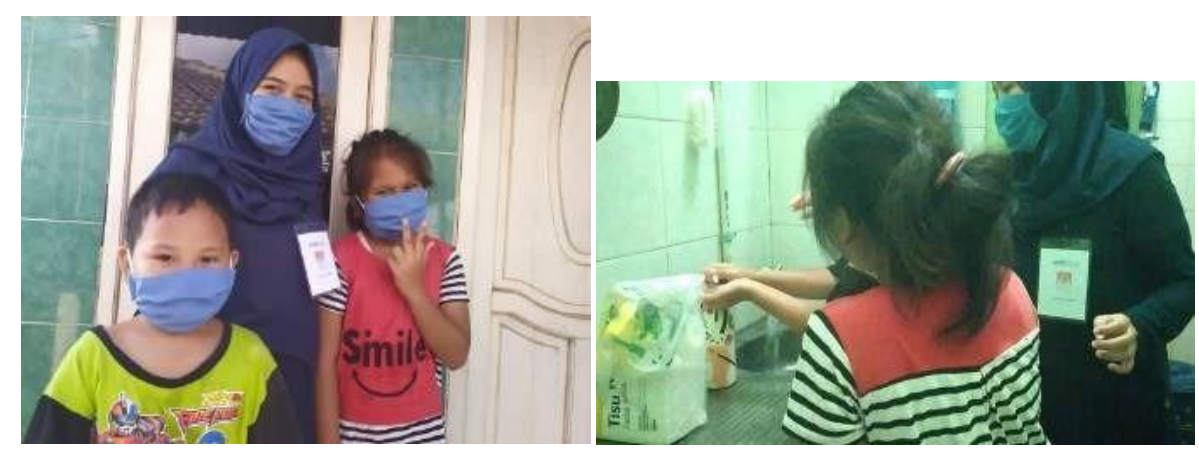


Gambar 9. Mencuci Tangan dalam PHBS Bersama Anak-Anak

e. Edukasi pembuatan Handsaitizer dan sabun Cair

Peserta didik juga diajarkan peralatan yang wajib dibawa saat keluar rumah di masa new normal, membuat handsanitizer, dan membuat sabun cair. Kegiatan ini dilakukan secara langsung dengan memperhatikan protokol kesehatan karena semua peserta diwajibkan menggunakan masker dan memakai handsanitizer. Bahkan, sebelum pembelajaran dimulai peserta diwajibkan untuk mencuci tangan terlebih dahulu dengan bimbingan cara mencuci tangan yang benar.

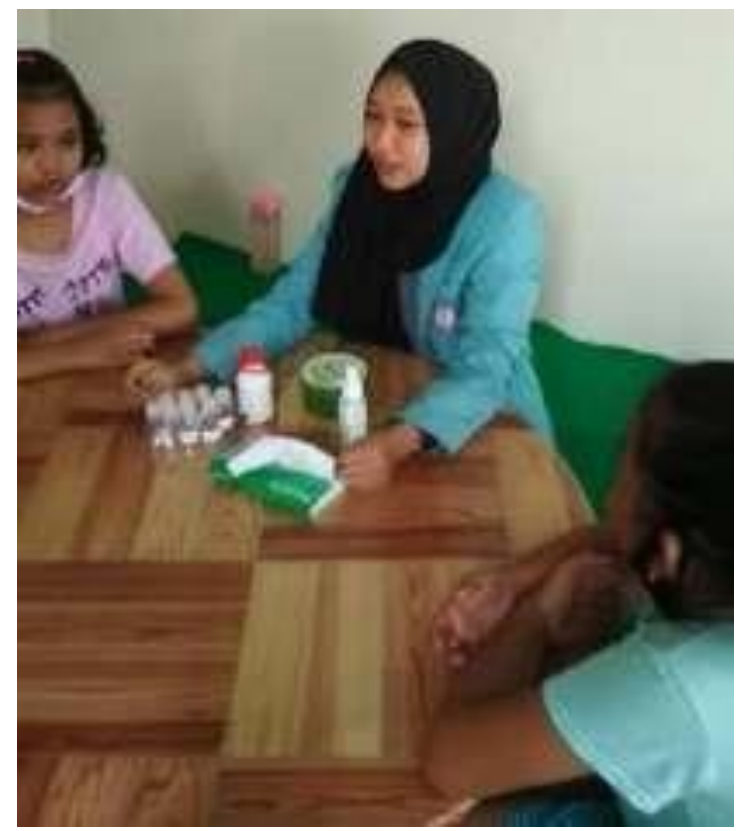

Gambar 10. Sosialisasi cara membuat handsanitizer secara mandiri

\section{KESIMPULAN}

Kegiatan kuliah kerja nyata (KKN) covid 19 berjalan dengan baik dan lancar dengan berbagai adaptasi baru. Kegiatan yang membuahkan hasil yang positif dimana masyarakat lebih memahami akan COVID-19, New Normal, serta protokol kesehatan yang harus dijalankan. masyarakat sekitar juga menjadi lebih memahami mengenai penggunaan masker yang baik serta panduan mencuci tangan yang benar. Masyarakat juga terfasilitasi akan kebutuhan masker yang sangat penting selama wabah COVID-19 ini. Anak-anak pun dapat terfasilitasi belajarnya dan menjadi lebih paham pada pelajaran-pelajaran yang kurang 
dipahami. Selain itu, anak-anak juga merasa terhibur selama pembelajaran jarak jauh (PJJ) dan mendapatkan pemahaman-pemahaman baru yang belum didapatkan melalui bimbingan kelompok dengan sistem daring.

Daftar Pustaka

Guan WJ, Ni ZY, Hu Y, Liang WH, Ou CQ, He JX, et al. Clinical Characteristics of Coronavirus Disease 2019 in China. New Engl J Med. 2020; published online February 28. DOI: 10.1056/NEJMoa2002032.

Kottasova, I. (2020, Maret 17). Coronavirus Lockdowns: 24 Hours of Confusion Around the World. Retrieved from CNN Health: https://edition.cnn.com/2020/03/17/health /restrictions-lockdownsconfusioncoronavirus-intl/index.html

Perdana, P. R. (2020, Maret 18). Syarat Ketat Lockdown, RI Sanggup Nggak? Retrieved from detikFinance: https://finance.detik.com/beritaekonomibisnis/d 4943608/syarat-ketat-lockdownri-sanggup-nggak

Widiyani, R. (2020). Latar Belakang Virus Corona, Perkembangan hingga Isu Terkini. Retrieved from detikNews: https://news.detik.com/berita/d4943950/latar-belakang-virus coronaperkembangan-hingga-isu-terkini

Wilder-Smith, A., \& Freedman, D. O. (2020). Isolation, Quarantine, Social Distancing and Community Containment: Pivotal Role for OldStyle Public Health Measures in the Novel Coronavirus (2019nCoV) Outbreak. Journal of Travel Medicine, 27(2),1-4. https://doi.org/10.1093/jtm/taaa020

World Health Organization [WHO]. (2020). WHO Director-General's opening remarks at the media briefing on COVID-19 -11 March 2020. https://www.who.int/dg/speeches/detail/who-director-general-s-openingremarks-at-the-media-briefing-on-covid-19---11-march-2020

Yurianto, Ahmad, Bambang Wibowo, K. P. (2020). PEDOMAN PENCEGAHAN 
DAN PENGENDALIAN CORONAVIRUS DISEASE (COVID-19) (M. I. Listiana Azizah, Adistikah Aqmarina (ed.)). 